\title{
Magnesium-supplying power of some Finnish mineral soils
}

\author{
Armi Kaila and Helinä Kettunen \\ University of Helsinki, Department of Agricultural Chemistry
}

Received March 30, 1973

\begin{abstract}
Uptake of magnesium from a sand, fine sand, muddy clay, silty clay and heavy clay soil under exhaustive cropping with perennial rye grass was studied in green house.

An application of $0.5 \mathrm{~g} \mathrm{Mg}$ as $\mathrm{MgSO}_{4} \cdot 7 \mathrm{H}_{2} \mathrm{O}$ per the 5-liter pots increased slightly the total yield of rye grass shoots and markedly the amount of $\mathrm{Mg}$ harvested in the shoots from the sand and fine sand soils with an initial content of only 14 and 37 ppm exchangeable $\mathrm{Mg}$, respectively. No respond to the application of $\mathrm{Mg}$ was detected in the silty clay and heavy clay soils which contained exchangeable $\mathrm{Mg} 226$ and $910 \mathrm{ppm}$, respectively. The muddy clay soil contained $137 \mathrm{ppm}$ exchangeable $\mathrm{Mg}$, and the application of $\mathrm{Mg}$ markedly increased the amount of $\mathrm{Mg}$ harvested in the shoots, but brought about a decrease in the yield of shoots.

The amount of $\mathrm{Mg}$ harvested in the shoots without the application of $\mathrm{Mg}$ was only in the sand and fine sand soils higher than the original content of exchangeable $\mathrm{Mg}$. Yet, in all soils except in the muddy clay, the decrease in the content of exchangeable $\mathrm{Mg}$ during the cropping was lower than the amount of $\mathrm{Mg}$ harvested. This was taken to indica:e that some release of nonexchangeable $\mathrm{Mg}$ did occur during this trial. According to a rough estimation this mobilization of $\mathrm{Mg}$ varied from 0 to $60 \mathrm{ppm}$, whereas the corresponding release of nonexchangeable $\mathrm{K}$ was $500-1000 \mathrm{ppm}$, except in the sand soil.

The rexhaustion $\mathrm{Mg}$, or the sum of $\mathrm{Mg}$ harvested in the shoots of rye grass and the exchangeable $\mathrm{Mg}$ in the soil after cropping, was in all soils of the same order as the amount of $\mathrm{Mg}$ extracted by $0.05 \mathrm{~N}$ or $0.1 \mathrm{~N} \mathrm{HC1}$ from the original soil samples.
\end{abstract}

Nonexchangeable potassium released mainly from the clay fraction during a growing season may supply a marked part of the $\mathrm{K}$ in crops. The release of nonexchangeable $\mathrm{Mg}$ seems to be much slower (MichaEL and Schilling 1957), although under exhaustive cropping the uptake of $\mathrm{Mg}$ by plants may be somewhat higher than the corresponding decrease in the content of exchangeable $\mathrm{Mg}$ in the soil (SALmon and Arnold 1963, Schroeder et al. 1963, Rice and KAMprath 1968).

Finnish mineral soils are relatively rich in total $\mathrm{Mg}$ and also their content of exchangeable $\mathrm{Mg}$ is quite high, particularly in clay soils (KaILA 1973). An attempt is made in the present study to estimate to what extent $\mathrm{Mg}$ in different kind of our mineral soils may be taken up by plants. A trial 
on exhaustive cropping in greenhouse with rye grass was carried out with and without an application of $\mathrm{Mg}$ and the possible release of nonexchangeable $\mathrm{Mg}$ was estimated on the basis of soil analyses.

\section{Experimental}

The five soil samples used in the present work were all from the neighbourhood of Helsinki and represented the plough layer of soils of different texture (Table 1). The content of organic $\mathrm{C}$ is high in the silty clay and

Table 1. Soil samples

\begin{tabular}{ccccc} 
1. Sand & $\begin{array}{c}\text { 2. Fine } \\
\text { sand }\end{array}$ & $\begin{array}{c}\text { 3. Muddy } \\
\text { clay }\end{array}$ & $\begin{array}{c}\text { 4. Silty. } \\
\text { clay }\end{array}$ & $\begin{array}{c}\text { 5. Heavy } \\
\text { clay }\end{array}$ \\
\hline
\end{tabular}

Particle size fractions \%

$\begin{array}{rrrrrr}<2 \mu \mathrm{m} \ldots \ldots \ldots . & 3 & 12 & 46 & 30 & 76 \\ 2-20 \mu \mathrm{m} \ldots \ldots \ldots . . & 3 & 8 & 31 & 50 & 15 \\ 20-200 \mu \mathrm{m} \ldots \ldots \ldots \ldots & 30 & 68 & 20 & 15 & 7 \\ 200-2000 \mu \mathrm{m} \ldots \ldots \ldots \ldots & 64 & 12 & 3 & 5 & 2\end{array}$

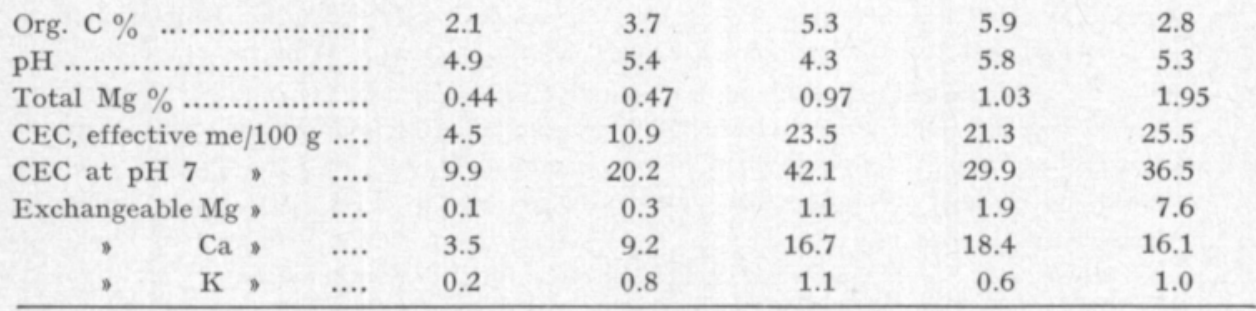

muddy clay samples. The original $\mathrm{pH}$ values measured in $0.02 \mathrm{~N} \mathrm{CaCl}_{2}$ is typically low in the muddy clay and also in the sand soil. The total content of $\mathrm{Mg}$ determined by sodium carbonate fusion does not differ from the average values found for the respective textural groups in a larger material of Finnish soils (KAILA 1973). The content of exchangeable Mg replaced by $\mathrm{N} \mathrm{NH}_{4} \mathrm{OAc}$ at $\mathrm{pH} 7$ is in the sand and fine sand soils very low in relation to the $\mathrm{CEC}$ and other exchangeable cations. In the heavy clay sample, on the other hand, the exchangeable $\mathrm{Mg}$ represents a marked part of the CEC, as it is typical of these soils (KAILA 1972).

The greenhouse trial was performed in 5-liter Mitscherlich pots with 4.8 $\mathrm{kg}$ of the air-dry and crushed samples of sand, fine sand and heavy clay, with $4.2 \mathrm{~kg}$ of the silty clay and with $3.8 \mathrm{~kg}$ of the muddy clay. In addition to these $2.4 \mathrm{~kg}$ of the heavy clay sample mixed with an equal weight of washed quartz sand was included.

As the basal dressing all pots received $10 \mathrm{~g}$ of a combined Finnish fertilizer $(\mathrm{N}: \mathrm{P}: \mathrm{K}=\mathbf{8}: 5.7: 7.5)$ and trace elements in solution. During the experimental period $\mathrm{N}$ as $\mathrm{NH}_{4} \mathrm{NO}_{3}$ solution was added three times to all pots, and $\mathrm{K}$ as $\mathrm{KCl}, \quad \mathrm{P}$ as $\mathrm{Ca}\left(\mathrm{H}_{2} \mathrm{PO}_{4}\right)_{2} \cdot \mathrm{H}_{2} \mathrm{O}$ and trace elements once. The 
acid muddy clay was limed with $50 \mathrm{~g} \mathrm{CaCO}_{3}$ per pot. One half of the pots received $5 \mathrm{~g}$ of $\mathrm{MgSO}_{4} \cdot 7 \mathrm{H}_{2} \mathrm{O}$. The trial was carried out with four replicates.

The trial was started in the summer 1968 when 40 seeds of perennial rye grass was sown to each pot. The shoots were harvested at unregular intervals until one of the replicates did no more grow. This happened with the sand soil after the fifth harvest, but the growth in the heavy clay was quite vigorous even until the twelfth harvest, when the trial was ended in the spring 1971.

The shoots of each replicate were at each harvest separately analysed for their content of $\mathrm{Mg}$ by dry-ashing. The soil from the pots without the application of $\mathrm{Mg}$ were at the end of the trial air-dried, and the roots were separated before grinding.

The original soil samples were analysed for their content of $\mathrm{Mg}$ soluble in $0.025 \mathrm{~N} \mathrm{CaCl}, \quad 0.01 \mathrm{~N} \mathrm{HCl}, \quad 0.05 \mathrm{~N} \mathrm{HCl}$ and $0.1 \mathrm{~N} \mathrm{HCl}$ at room temperature, and in $0.05 \mathrm{~N} \mathrm{HCl}, 0.1 \mathrm{~N} \mathrm{HCl} 0.5 \mathrm{~N} \mathrm{HCl}$ and $1.0 \mathrm{~N} \mathrm{HCl}$ at $50^{\circ}$. The ratio of soil to solution was in all cases 10 to 100 . The extraction at room temperature was performed by shaking for one hour, and at the higher temperature by keeping the suspension at $50^{\circ} \mathrm{C}$ for 18 hours. $\mathrm{Mg}$ in the extract was measured by a Perkin Elmer atomic absorption spectrophotometer 290 .

\section{Results}

The total yields of rye grass shoots (Table 2) were only slightly increased

Table 2. Total yields of rye grass shoots and of $\mathrm{Mg}$ harvested in the shoots

\begin{tabular}{|c|c|c|c|c|c|}
\hline \multirow{2}{*}{ Soil } & \multirow{2}{*}{$\begin{array}{l}\text { Number of } \\
\text { harvests }\end{array}$} & \multicolumn{2}{|c|}{ Shoots g/pot* } & \multicolumn{2}{|c|}{$\mathrm{Mg}$ in shoots $\mathrm{mg} /$ pot* } \\
\hline & & without $\mathrm{Mg}$ & Mg applied & without $\mathrm{Mg}$ & Mg applied \\
\hline 1. Sand .................... & 5 & $74 \pm 5$ & $89 \pm 7$ & $75 \pm 2$ & $307 \pm 30$ \\
\hline 2. Fine sand ............ & 11 & $183 \pm 4$ & $196 \pm 4$ & $244 \pm 25$ & $557 \pm 17$ \\
\hline 3. Muddy clay ........... & 11 & $282 \pm 14$ & $226 \pm 6$ & $442 \pm 10$ & $671 \pm 11$ \\
\hline 4. Silty clay ............... & 10 & $220 \pm 13$ & $216 \pm 11$ & $676 \pm 17$ & $726 \pm 39$ \\
\hline 5. Heavy clay .......... & 12 & $241 \pm 20$ & $240 \pm 5$ & $827 \pm 81$ & $843 \pm 16$ \\
\hline $\begin{array}{l}\text { 6. Heavy clay }+ \\
\text { quartz sand ........... }\end{array}$ & 12 & $230 \pm 6$ & - & $794 \pm 95$ & - \\
\hline
\end{tabular}

*Mean values with confidence limits at the $95 \%$ level.

by the application of $\mathrm{Mg}$ in the sand and fine sand soils. In the other soils no positive response was found: the total yield in the muddy clay soil was even somewhat decreased by the $\mathrm{MgSO}_{4}$ applied. Yet, the total amount of $\mathrm{Mg}$ harvested from the muddy clay was markedly increased by the $\mathrm{Mg}$ application, as it also was the case with the $\mathrm{Mg}$-yields from the sand and fine sand soils. In the silty clay and, particularly, in the heavy clay soil, 
the available $\mathrm{Mg}$ was so high that no distinct response was detectakle. The very good supply of $\mathrm{Mg}$ in the heavy clay soil is apparent also in the fact that the growth and the uptake of $\mathrm{Mg}$ from the sample diluted with quartz sand were not significantly lower than from the undiluted soil.

Without an application of $\mathrm{Mg}$ only five harvests of rye grass shoots could be obtained from the sand soil. The amount of $\mathrm{Mg}$ in this material corresponded to $16 \mathrm{ppm}$ of the soil (Table 3) which seems to be somewhat higher than

Table 3. Estimation of the $\mathrm{Mg}$-balance in the pot experiment (Expressed as ppm of the soil)

\begin{tabular}{|c|c|c|c|c|c|c|}
\hline & \multirow{2}{*}{$\begin{array}{l}\mathrm{Mg} \\
\text { harvested } \\
\text { in shoots }\end{array}$} & \multicolumn{3}{|c|}{ Exchangeable $\mathrm{Mg}$ in soils } & \multicolumn{2}{|c|}{$\begin{array}{c}\text { Released from } \\
\text { nonexchangeable }\end{array}$} \\
\hline & & original & at the end & difference & $\mathrm{Mg}$ & K \\
\hline 1. Sand ........... & 16 & 14 & 9 & 5 & 11 & 10 \\
\hline 2. Fine sand ... & 51 & 37 & 8 & 29 & 22 & 520 \\
\hline 3. Muddy clay. & 116 & 137 & 14 & 123 & 0 & 540 \\
\hline 4. Silty clay .... & 161 & 226 & 122 & 104 & 57 & 990 \\
\hline 5. Heavy clay. & 172 & 910 & 788 & 122 & 50 & 990 \\
\hline
\end{tabular}

the content of exchangeable $\mathrm{Mg}$ in the soil before cropping. Also the amount of $\mathrm{Mg}$ in the shoots of eleven harvests from the fine sand soil was higher than the original content of exchargeable $\mathrm{Mg}$. In both these soils, the decrease in the content of exchangeable $\mathrm{Mg}$ was markedly lower than the amount of $\mathrm{Mg}$ harvested, and this was also the case with the silty clay and heavy clay soils, in spite of their high original content of ecxhangeable $\mathrm{Mg}$. This may be taken to indicate that release of nonexchangeable $\mathrm{Mg}$ did occut during the trial. In muddy clay the decrease in the content of exchangeable $\mathrm{Mg}$ was enough to support the eleven crops with $\mathrm{Mg}$.

The release of nonexchangeable $\mathrm{K}$ from these soils during cropping was also estimated in the same way and supposing that the $\mathrm{K}$ applied as soluble salts was totally taken up by the crops. Except in the sand soil, the release of $\mathrm{K}$ appeared to be fairly high and quite of an other order than that of $\mathrm{Mg}$.

In their paper about uptake of $\mathrm{Mg}$ over exhaustive cropping SALMON and ARNOLD (1963) use the term mexhaustion Mg» to mean the sum of the amount of $\mathrm{Mg}$ taken up by the plants and the content of easily exchangeable $\mathrm{Mg}$ in the soil at the end of the cropping. The mexhaustion Mg of the present soils (Table 4) ranges from about 0.5 per cent of the total $\mathrm{Mg}$ in the sand soil to 5 per cent in the heavy clay soil. It is in all soils only a small fraction of the amount of $\mathrm{Mg}$ released by the treatment with $\mathrm{N} \mathrm{HCl}$ at the higher temperature. It is of the order of the amounts extracted by $0.05 \mathrm{~N} \mathrm{HCl}$ or $0.1 \mathrm{~N} \mathrm{HCl}$ at the room temperature.

According to Schachtschabel (1954 and 1956) sandy soils with less than $40 \mathrm{ppm}$ and clay soils with less than $120 \mathrm{ppm}$ of $\mathrm{Mg}$ extractable with 0.025 $\mathrm{N} \mathrm{CaCl}_{2}$ are deficient in $\mathrm{Mg}$. These test values in Table 4 classify the sand and fine sand soil distinctly deficient in $\mathrm{Mg}$, the silty clay and heavy 
Table 4. Exhaustion $\mathrm{Mg}$, and $\mathrm{Mg}$ extracted by various treatments ( $\mathrm{Mg} \mathrm{ppm}$ of soil)

\begin{tabular}{|c|c|c|c|c|c|}
\hline & 1. Sand & $\begin{array}{l}\text { 2. Fine } \\
\text { sand }\end{array}$ & $\begin{array}{l}\text { 3. Muddy } \\
\text { clay }\end{array}$ & $\begin{array}{l}\text { 4. Silty } \\
\text { clay }\end{array}$ & $\begin{array}{l}\text { 5. Heavy } \\
\text { clay }\end{array}$ \\
\hline $\begin{array}{l}\text { Exhaustion Mg ........ } \\
\text { Mg extracted by }\end{array}$ & 25 & 59 & 130 & 283 & 960 \\
\hline $0.025 \mathrm{~N} \mathrm{CaCl}_{2} \ldots \ldots$ & 9 & 26 & 100 & 157 & 497 \\
\hline $0.01 \mathrm{~N} \mathrm{HCl} \ldots \ldots \ldots$ & 12 & 29 & 105 & 134 & 395 \\
\hline $0.05 \mathrm{~N} \mathrm{HCl} \ldots \ldots \ldots$ & 17 & 41 & 131 & 236 & 876 \\
\hline $0.1 \mathrm{~N} \mathrm{HCl} \ldots \ldots \ldots . .$. & 28 & 61 & 175 & 345 & 1400 \\
\hline $0.05 \mathrm{~N}$ at $50^{\circ} \mathrm{C} \ldots$. & 66 & 145 & 199 & 415 & 1180 \\
\hline $0.1 \mathrm{~N} \mathrm{HCl}, \ldots \ldots$ & 212 & 312 & 425 & 835 & 1887 \\
\hline $0.5 \mathrm{~N} \mathrm{HCl}, \ldots \ldots$ & 720 & 1060 & 2862 & 3300 & 5980 \\
\hline $1 \mathrm{~N} \mathrm{HCl}, \ldots \ldots$ & 970 & 1432 & 5150 & 5410 & 10980 \\
\hline Exchangeable $\mathrm{Mg} . . . . .$. & 14 & 37 & 137 & 226 & 910 \\
\hline
\end{tabular}

clay soils to be not in need of $\mathrm{Mg}$ fertilizers, and the muddy clay likely to be slightly short of available $\mathrm{Mg}$.

\section{Discussion}

There were several weak points in the present study. The growing conditions during the first months were not proper, and the growth during the winter months was scanty. Because difficulties in avoiding contamination with soil, roots were not analysed for their content of $\mathrm{Mg}$. On the other hand, the amount of $\mathrm{Mg}$ in the seeds was not taken into account. It is also likely that in this kind of longterm pot trial other factors than the supply of available $\mathrm{Mg}$ restricted the growth of rye grass.

Even in spite of the numerous sources of error, it seems that some release of nonexchangeable $\mathrm{Mg}$ did occur during cropping in these soils, except in the muddy clay. It is possible that even in this soil some nonexchangeable $\mathrm{Mg}$ was released, but because of its rather heavy liming, also conversion of $\mathrm{Mg}$ to nonexchangeable forms took place (cf. McLEAN and CARBonelL 1972).

The absolutely low but in relation to the uptake fairly high release of $\mathrm{Mg}$ in the sand soil is in accordance with the results reported by RICE and KAMprath 1968). They explain this release on the basis of the low buffer capacity of sand soils which allows the $\mathrm{H}$-ions from the roots to be quite effective in extracting the $\mathrm{Mg}$ from nonexchangeable forms. In this trial the end $\mathrm{pH}$ of the sand soil was only 4.3 .

Schachtschabel (1956) used $0.05 \mathrm{~N} \mathrm{HCl}$ for the extraction of the available $\mathrm{Mg}$ and the easily mobilizeable reserve $\mathrm{Mg}$. In the five soils of the present study the mexhaustion $\mathrm{Mg}$ " was equal or somewhat higher than the $\mathrm{Mg}$ extracted by $0.05 \mathrm{~N} \mathrm{HCl}$. It is obvious that a treatment of soil with $\mathrm{N} \mathrm{HCl}$ or other acid at a higher temperature will give a far too high estimate of the reserve $\mathrm{Mg}$ of soil. In the present study, the nexhaustion $\mathrm{K}$ " corresponded in the sand and fine sand soil to about $80 \%$ and in the clay soils to $30-$ $40 \%$ of the $\mathrm{K}$ extracted by $\mathrm{N} \mathrm{HCl}$ at $50^{\circ} \mathrm{C}$. 


\title{
REFERENCES
}

KaILA, A. 1972. Basic exchangeable cations in Finnish mineral soils J. Scient. Agric. Soc. Finl. 44: 164-170.

-1 1973. Calcium, magnesium and potassium in mineral soils of the southern half of Finland. J. Scient. Agric. Soc. Finl. 45: 254-261.

McLean, E. O. \& Carbonell, M. D. 1972. Calcium, magnesium, and potassium saturation ratios in two soils and their effects upon yields and nutrient contents of German millet and alfalfa. Soil Sci. Soc. Amer. Proc. 36: 927-930.

Michael, G. \& Schilling, G. 1957. Über den Magnesiumversorgungsgrad mitteldeutscher Ackerböden. Z. Pflanzenern. Düng. Bodenk. 79: 31-50.

Rice, H. B. \& Kamprath, E. J. 1968. Availability of exchangeable and nonexchangeable $\mathrm{Mg}$ in Sandy Coastal Plain Soils. Soil Sci. Soc. Amer. Proc. 32: 386-388.

SALMon, R. C. \& ARNold, P. W. 1963. The uptake of magnesium under exhaustive cropping. J. Agric. Sci. 61: 421-425.

SснаснтsснавеL, P. 1954. Das pflanzenverfügbare Magnesium des Bodens und seine Bestimmung. Z. Pflanzenern. Düng. Bodenk. 67: 9-23.

- - 1956. Der Magnesiumversorgungsgrad nordwestdeutscher Böden und seine Beziehungen zum Auftreten von Mangelsymptomen an Kartoffeln. Z. Pflanzenern. Düng. Bodenk. 74: $202-219$.

Schroeder, D., Zahiroleslam, S. \& Hoffmann, W. E. 1963. Untersuchungen über die Verfügbarkeit der Magnesiumvorräte des Bodens. Z. Pflanzenern. Düng. Bodenk. 100. $215-224$.

\section{Selostus}

\section{Eräiden kivennäismaiden käyttökelpoisista magnesiumvaroista}

\author{
Armi Kaila ja Helinä Kettunen \\ Yliopiston maanviljelyskemian laitos, Viikki
}

Pitkäaikaista astiakoetta käyttäen tutkittiin raiheinän magnesiumin ottoa hiekasta, hiedasta, liejusavesta, hiesusavesta ja aitosavesta. Magnesiumlannoitus lisäsi jonkin verran raiheinän kokonaissatoa ja runsaasti sadossa korjatun magnesiumin määrää hiekka- ja hietamaassa, mutta ei vaikuttanut merkitsevästi hiesu- tai aitosaven antamiin tuloksiin. Liejusaven antama raiheinäsato aleni hiukan, mutta samalla sadossa korjatun magnesiumin määrä nousi merkittävästi magnesiumlannoituksen ansiosta.

Sadoissa korjatun magnesiumin määrä oli hiekka- ja hietamaassa suurempi kuin maitten alkuperäinen vaihtuvan magnesiumin pitoisuus. Maan vaihtuvan magnesiumin väheneminen kokeen aikana oli kuitenkin liejusavea lukuunottamatta selvästi pienempi kuin sadoissa korjattu magnesiumin määrä. Näin ollen näyttää ilmeiseltä, että kokeen aikana on vapautunut jonkin verran vaihtumatonta magnesiumia. Tämän määrän arvioitiin olevan $0-60 \mathrm{mg} / \mathrm{kg}$ maata, kun taas vastaavan kaliumin mobilisoitumisen todettiin hiekkamaata lukuunottamatta olevan $500-1000 \mathrm{mg} / \mathrm{kg}$.

Kasvien ottaman ja kokeen loputtua maassa olevan vaihtuvan magnesiumin summa vastasi alkuperäisistä maista 0.05 tai $0.1 \mathrm{n}$ HCl:lla uutettavissa olevaa magnesiumin määrää.

H u o m a u t u s. August Johannes ja Aino Tiuran Maatalouden Tutkimussäätiö myőnsi maisteri Ritva Rytille vv. 1968-69 apurahan tutkimustyöhön, johon edellä selostettu astiakoe kuului. Maisteri Rytin kuoleman jälkeen kokeen hoiti itsenäisesti laborantti Kaija Tuominen, joka myös on suorittanut osan analyysityőstä. 